\title{
WHO TAKES A MOOC? PROFILE OF STUDENTS IN THE FRAMEWORK OF A EUROPEAN PROJECT
}

\author{
Dr. Elia FERNANDEZ-DIAZ \\ ORCID: 0000-0003-0647-260X \\ Faculty of Education, University of Cantabria \\ Santander, SPAIN \\ Dr. Carlos RODRIGUEZ-HOYOS \\ ORCID: 0000-0002-6949-6804 \\ Faculty of Education, University of Cantabria \\ Santander, SPAIN \\ Dr. Jose Luis BELVER DOMINGUEZ \\ ORCID: 0000-0001-7790-9157 \\ Faculty of Teacher Training and Education, University of Oviedo \\ Oviedo, SPAIN \\ Dr. Adelina CALVO SALVADOR \\ ORCID: 0000-0002-9262-7905 \\ Faculty of Education, University of Cantabria \\ Santander, SPAIN
}

Received: 16/04/2019 Accepted: 05/08/2019

\begin{abstract}
This research analyzes the profile of students on MOOC (massive open online courses) courses within the framework of the ECO project (E-learning, Communication and Open-Data: Massive Mobile, Ubiquitous and Open Learning) promoted by the European Union. An analysis of the profile of students enrolled in the five editions of the course entitled "Educational innovation and professional development. Possibilities and limits of technology" has been conducted based on the following objectives: (a) gain knowledge about the profile of students; (b) identify the students' perception of their level of digital competence for participating in the course; (c) find out what their real expectations were when they enrolled on the course; and (d) suggest proposals for improving the design of the course based on the study carried out on the student profile. This research shows the tendencies of students enrolled on these types of training processes and suggests improvements in the design of the course in order to satisfy the participants' motivations and expectations. In this regard, the results suggest that the design of MOOCs should be based on a sustainable, social and communicative curricular approach while at the same time greatly enhancing interaction and collaborative work.
\end{abstract}

Keywords: MOOC, higher education, virtual education, open education

\section{INTRODUCTION}

Following the expansion of the phenomena of massive open online courses (MOOC), different lines and areas of research have been addressed to reflect on the nature and implications of this training modality and there have been multiple reflections and contributions on the hypothetical disruptive potential of these courses which are currently experiencing a boom.

The abundant scientific literature generated with respect to the appearance and development of these courses has not prevented some subjects being addressed less frequently. Recent studies on the bibliometric impact of the scientific literature generated around MOOC highlight the scarcity of work aimed at analyzing the main characteristics of the participants in these types of experiences. In this regard, in the analysis of the 
scientific literature carried out by Zancanaro and Domingues (2017) using the thematic classification by Liyanagunawardena, Adams, and Williams (2013) and Yousef, Chatti, Schroeder, Wosnitza, and Jakobs (2014), only five papers focused on analyzing the profile of the target audience were identified (Adamopoulos, 2013; Kravvaris, Ntanis, \& Kermanidis, 2013; Sanchez-Gordon \& Lujan-Mora, 2013, among others) compared to a considerably higher number of studies on other topics such as type of study, design and technology, conceptual aspects, business models, or learning theories.

Nonetheless, some studies have contributed to identifying the main characteristics of the profiles of MOOC participants. Research carried out in this area reveals that the user profile for these courses is a middle aged person with higher education qualifications and mostly from countries of the North whose main motivation is extending their knowledge, something which is also facilitated by the free nature of this training modality (Barcena, Martin-Monje, \& Read, 2015; Bernal Gonzalez, Sanchez Vera, \& Prendes Espinosa, 2016; Christensen et al., 2013; Daniel, 2012; Martin-Monje \& Castrillo, 2016; Radford et al., 2014; Rubio, Fuchs, \& Dixon, 2016; Telefonica Foundation, 2015; University of Edinburgh, 2013; White, Davis, Dickens, Leon, \& Sanchez Vera, 2015). However, further research is required on the characteristics of students with the aim of being able to study in-depth the interpretation of the motivational, attitudinal and socio-economic factors, beyond the commonly recorded evidence (Alarios-Hoyos, Estevez-Ayres, PerezSanagustin, Delgado, \& Fernandez-Panadero, 2017; Castano, Maiz, \& Garay, 2015; De Waard et al., 2011; Fini, 2009).

The characterization of the socio-demographic profile is based on variables such as gender, age, geographical location or level of education. If the results provided by the HarwardX platform and University of Edinburgh (2015) platform are used as a reference, it can be seen that the platforms located in four English speaking countries (the US, UK, India and Canada) have more than half of all the students participating in these types of courses. Most of the participants (between 60-80\%) have higher education qualifications and the average age is above 30 years old in the countries of the North, while in developing countries it is below 30 . Although a greater number of men are identified, gender is closely related to the subject of the course.

As far as motivational aspects are concerned, the first studies carried out show that the participants are students or workers related to the subject of the course with the main motive being increasing knowledge and satisfying their curiosity (Brown, 2013; Kizilcec, Piech, \& Schneider, 2013; Kolowich, 2012). It does not appear that other motivational factors whether they are obtaining qualifications or the possibility of interacting with other people with similar interests and being able to form part of a virtual community are reasons that lead people to participate in these experiences (Telefonica Foundation, 2015). In addition, recent contributions continue to show that these courses are generally taken because they extend knowledge without sufficient evidence being found to link the decision to take a MOOC to the possibility of accessing the labour market. On the other hand, the wide variety of subjects offered, along with the fact that a high percentage of participants already have a job, suggests that the MOOC phenomena far from constituting a threat to regulated university education, is in fact an opportunity and is complementary to it (Aguado, 2017).

\section{A REVIEW OF THE CONTRIBUTIONS MADE IN RELATION TO MOTIVATIONAL ASPECTS}

Firstly, given that the diversity and complexity of MOOC participants is not only linked to demographic and cultural aspects but rather to the objectives that the users pursue when enrolling on a course, it can be asked how the design and typology of MOOC influence the participants' enrolment potential. Despite the predominance of xMOOCs based on a controlled, teacher focused hierarchical model, various studies demonstrate the participants' preferences for courses based on a focus of connectivism, collaboration and a concept of learning that aims to place the student at the centre of these types of educational processes (Osuna-Acedo \& Gil-Quintana, 2018; Yousef, Chatti, Wosnitza, \& Schroeder, 2015).

Along these lines, some studies illustrate the relevance of the format and curricular design of the course (Bentley et al., 2014; Sanchez-Vera, Leon-Urrutia, \& Huge, 2015), since these aspects can condition both the selection of the course as well as the involvement and participation of students (Hill, 2013a; 2013b) and have an influence on the completion rate (Yang, Shina, Adamson, \& Rosa, 2013). The study by RodriguezAcaso and Boticario (2015) highlights the importance of providing a friendly and accessible format in the design of the course, key issues for engaging students. 
Researching the curricular design of a MOOC course also implies questioning the underlying pedagogical and communicative model. Based on previous work in this field (Barcena \& Read, 2015; Colpaert, 2016; Godwin-Jones, 2014; Perifanou, 2015; Read, 2014; Rubio et al., 2016; Sharples, Delgado, Dimitriadis, Garlatti, \& Specht, 2015; Teixeira, Garcia-Cabot, Garcia-Lopez, Mota, \& De-Marcos, 2016; Teixeira \& Mota, 2014; Torres \& Gago, 2014) the study by Sedano Cuevas (2017) identifies some of the premises on which the design of these courses should be focused in order to provide a suitable curricular and communicative design: contextualized and functional design; adaptive learning to detect needs, progress and shortcomings; modularity, flexibility and scalability; training and experiential assessment, collaboration tools and external social networks, gamification, ubiquity and adaptation to m-learning.

Some studies suggest the need to develop more sophisticated tools by educators, designers and programmers (Chang \& Wei, 2016; Daniel, Vazquez Cano, \& Gisbert, 2015), to improve adaptability in design, facilitating access through mobile devices and increasing the understanding of user profiles and needs (Brazuelo \& Cacheiro, 2016; Dillahunt, Wang, \& Teasly, 2015; Kim 2015). In addition, other works suggest the incorporation of gamification techniques in the planning, design, implementation and use of MOOCs through models based on collaboration (Gonzalez, Collazos, \& Garcia, 2016). Given that enjoyment and fun are among the most important reasons for enrolling on a course (Belanger \& Thornton, 2013), it is necessary to continue researching formulas and strategies required for courses to become sufficiently attractive and interactive.

On the other hand, it is relevant to continue looking at the specific needs of the participants. Although the literature in this field has shown that MOOCs experience high dropout rates (Armstrong, 2014; Belanger \& Thorton, 2013; Fidalgo Blanco, Sein-Echaluce, \& Garcia-Penalvo, 2015; Jordan, 2014; Koller, Ng, Do, \& Chen, 2013; Poy \& Gonzales-Aguilar, 2014; Yang et al., 2013), there needs to be an in-depth analysis of the design of courses and the way in which this design can facilitate the development of different training itineraries. Although in some courses taking all the modules for completion is required, in other cases the independent character of these allows participants to select contents and relevant tasks. Together with the information that the completion rate can provide, research on the students' evaluation of the course and their level of satisfaction is required (Gonzalez \& Carabantes, 2017). There should be further analysis into these issues in order to carry out an adequate interpretation of the data based on a practical perspective, given that the participants may have resolved the cognitive needs that motivated their enrolment without having to take or complete the entire course (Aguado, 2017; Wang \& Baker, 2018; Zhou, 2017).

Likewise, several studies question the findings and conclusions derived from calculations based on the completion rate. Users can see that their objectives have been achieved if they coincide with their initial expectations, which do not necessarily need to be linked to the completion of the course. In addition, the desirability of progressing towards hybrid designs capable of responding to the different needs of a wide and diverse number of people is recognized (Castano, Maiz, \& Garay, 2015; Milligan, Littlejohn, \& Margaryan, 2013; Yousef et al., 2015).

\section{METHODOLOGY AND DESIGN OF THE RESEARCH}

\section{Research Objectives and Contextualization of the Study}

The main objective of this research was to gain knowledge about the profile of students taking MOOC courses. In our opinion, this information is essential in order to achieve a greater adaptation of the pedagogical design of these courses to the expectations of the participants, something which can indirectly contribute to increasing completion rates, although this should not constitute the sole purpose in these types of processes (Koller et al., 2013).

This research has been carried out within the framework of a project aimed at the creation and development of MOOCs, entitled "Elearning, Communication and Open-Data: Massive Mobile, Ubiquitous and Open Learning (ECO)". The project focused on designing, developing and evaluating 17 MOOCs for trainers and teachers from all levels of education with the aim of providing them with the basic tools for developing these types of courses, mainly through mobile technologies, as well as the skills required for specialising in different fields according to the subject of the course (educational innovation, mobile communication 
and learning, the possibilities of ubiquitous learning for avoiding social exclusion, the relationship between digital tools and the MOOCs themselves, among others). Participants enrolled in this project also have the opportunity to create their own MOOC. The main goal of this project is to broaden access to education and to improve the quality and cost-effectiveness of teaching and learning in Europe. From 54219 students who enrolled in the courses, 4000 became e-teachers with the option of developing their own MOOC in ECO. The project involved 24 partners from 9 different countries (Spain, Netherlands, United Kingdom, Portugal, Italy, Germany, France, Colombia and Argentina). Along with the wide range of courses offered, another significant aspect is the use of several languages (Spanish, Italian, English, etc.) for its development. The ultimate goal was not simply to attract users for these courses, rather this training scheme was presented as an opportunity to create communities of professionals who can use these open training strategies for their own professional development. This not only involves complex technological deployment, but also in-depth review of the pedagogy of MOOCs which maintains the motivation of the participants and enables the successful completion of the proposed courses.

Within the framework of the project described above, we decided to analyze the profile of students enrolled in the five editions (developed between 2014 and 2017) of the course entitled "Educational innovation and professional development. Possibilities and limits of ICT", shown in figure 1, with the purpose of achieving the following objectives:

- Gaining knowledge about the profile of the students enrolled on the MOOC course.

- Identifying the students' own perception of their level of digital competence.

- Finding out what their real expectations were when they enrolled on the MOOC course.

- Suggesting proposals for improving the design of the course based on the study carried out on the student profile.

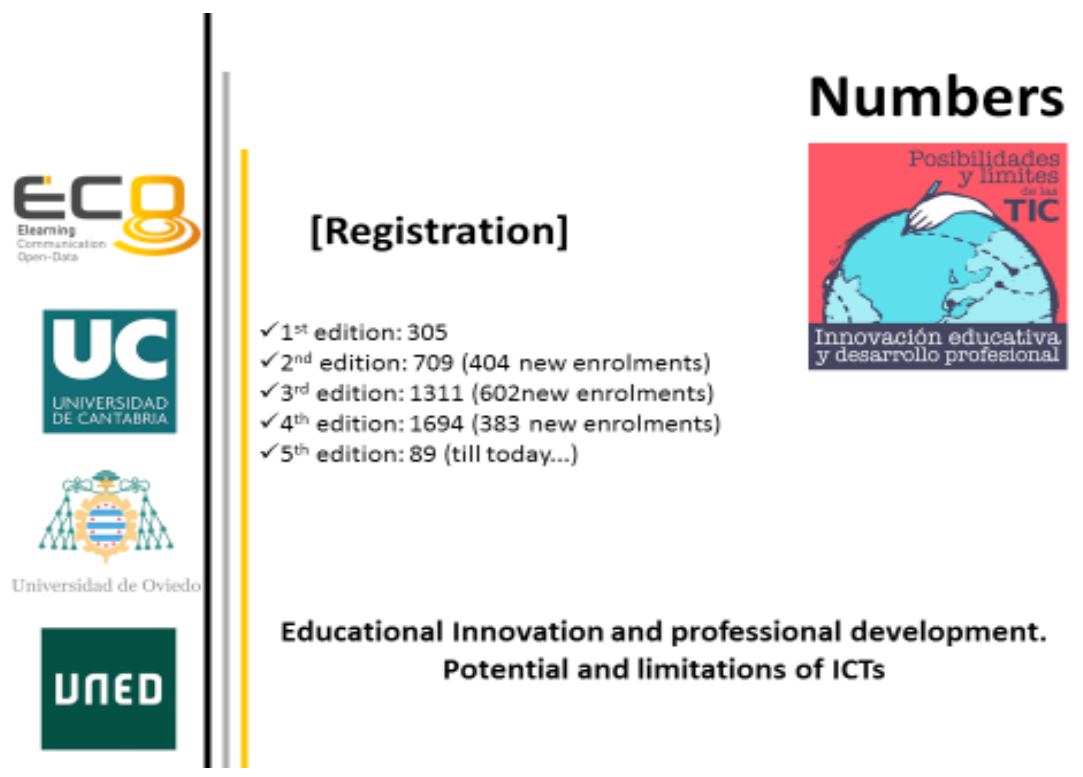

Figure 1. Evolution of enrolment in the 5 editions of the course

From a methodological perspective, the design of this research can be typified as quantitative, survey-based (McMillan \& Schumacher, 2001).

\section{Tool}

For the analysis of the profiles, interests and expectations of students enrolled in the cited MOOC, a semistructured questionnaire was designed. It is important to highlight that this questionnaire was replicated in all the editions of the MOOC analysed (5 editions) which allows us to exclude the formulation of items as a possible source of bias. In the following table (Table 1) the items included in the questionnaire that we designed. 
Table 1. Items in the initial questionnaire 'Profiles, interests and expectations'

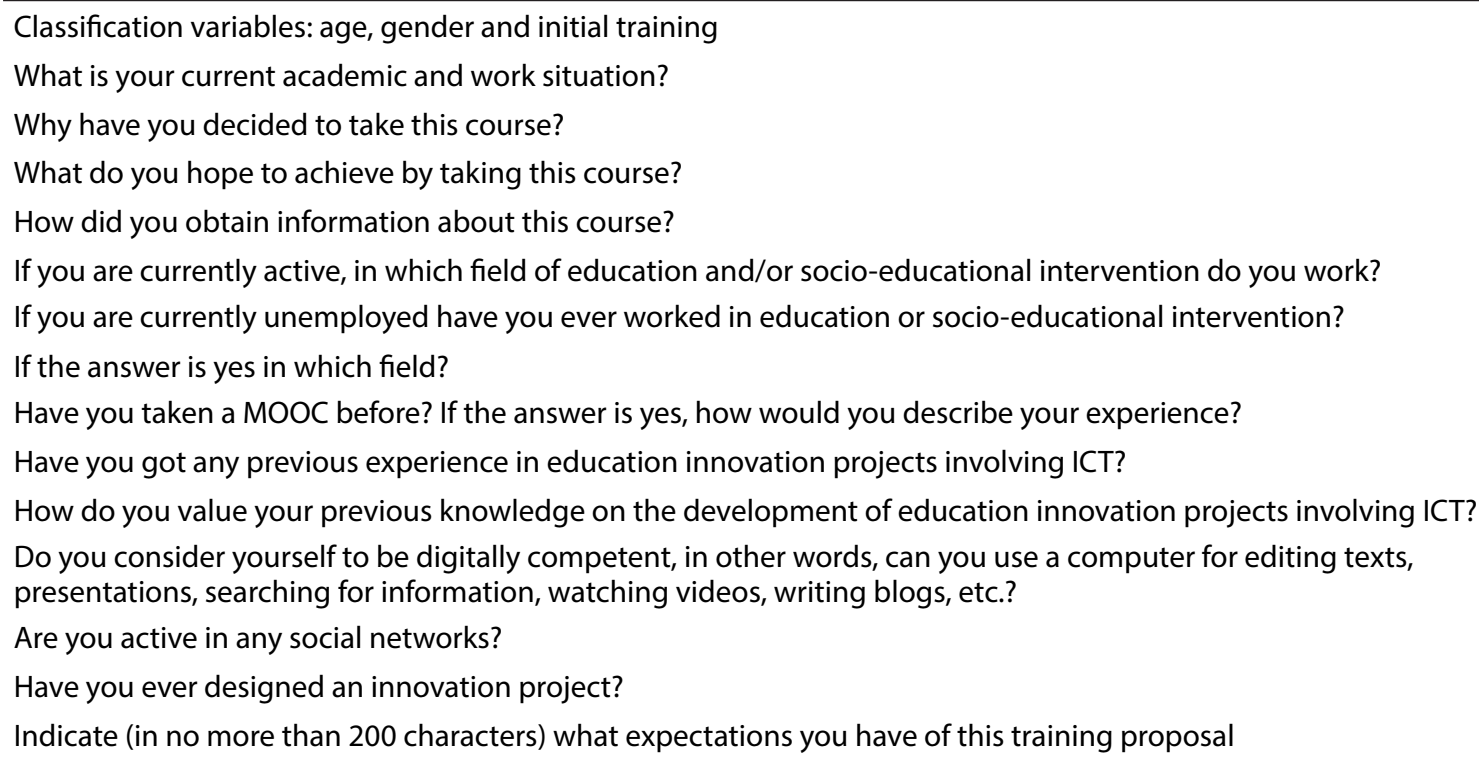

\section{Sample and Analysis of Data}

To carry out the study a non-probabilistic sample (convenience sampling) was used, a group of subjects on the basis of being accessible was selected for this purpose. The final sample rose to 715 subjects who voluntarily responded to the questionnaire sent at the start of each edition out of the 1789 students enrolled in the five editions of the course under analysis. This sample ( $\mathrm{n}=715)$ allows us to assume a level of confidence of $99.00 \%(\mathrm{Z}=2.58)$ with a sampling error of $4.00 \%$ (e) and a value of $\mathrm{p}$ and $\mathrm{q}$ of 0.5 , as a safer option in these types of cases. We would like to highlight that the research team is conscious that the use of non-probabilistic sampling limits the generalization of results, as well as the performance of a certain type of analysis of the data collected.

For data analysis we used a descriptive technique rather than inferential statistics (for example, $\mathrm{T}$ for Student or their parametric alternatives) given the possibility of existing auto-selection bias (Birnbaum, 2004), both in relation to voluntary enrolment on the course and the response to the questionnaire (voluntary) and which could imply that the results were representative or not of a group (students taking a MOOC course at a generic level). Given this situation we decided to exclusively compare frequencies and percentages with the aim of identifying tendencies and differences, without considering the possible statistic meaning of these. These percentages have been calculated for each item on the questionnaire with respect to the total number of responses per edition and the overall total.

Finally, it is important to highlight that all the research meets the ethical guidelines, including adherence to the legal requirements, within the framework of the ECO project. Participants were informed of academic usage and information privacy principles.

\section{RESULTS}

In the following section we will look at some of the main results of the study and their relation to our research objectives.

\section{Student Profile}

One of the first issues students were asked about was their age. In our opinion, we regarded it as a factor that could allow us to anticipate some of the possible problems linked to the management of the platform and monitoring MOOC. Of the total number of students who answered the questionnaire in the 5 editions (Ed) of the course $(n=715)$ more than $28 \%(28.25 \% ; n=202)$ belonged to the age range between $30-40$ 
years old, while nearly $25 \%$ were aged between $40-50$ years old $(24.9 \% ; n=178)$. The next largest group was aged between 18 to 25 years old $(20.84 \%$; $=149)$ followed by the group aged between 25 and 30 years old $(14.13 \% ; \mathrm{n}=101)$. The least represented groups in the course were those aged between 50 and 60 years old, higher than $9 \%(9,37 \% ; n=67)$ and those over 60 years old $(2.52 \% ; n=18)$.

Table 2. Age of participants

\begin{tabular}{|c|c|c|c|c|c|c|c|c|c|c|c|c|}
\hline \multirow{2}{*}{ Age } & \multicolumn{2}{|c|}{ 1st_Ed } & \multicolumn{2}{|c|}{ 2nd_Ed } & \multicolumn{2}{|c|}{ 3rd_Ed } & \multicolumn{2}{|c|}{ 4th_Ed } & \multicolumn{2}{|c|}{ 5th_Ed } & \multicolumn{2}{|c|}{ TOTAL } \\
\hline & $f$ & $\%$ & $f$ & $\%$ & $f$ & $\%$ & $f$ & $\%$ & $f$ & $\%$ & $f$ & $\%$ \\
\hline $18-25$ & 30 & $19.23 \%$ & 14 & $11.76 \%$ & 78 & $31.33 \%$ & 27 & $16.36 \%$ & 0 & $0.00 \%$ & 149 & $20.84 \%$ \\
\hline $25-30$ & 27 & $17.31 \%$ & 17 & $14.29 \%$ & 35 & $14.06 \%$ & 19 & $11.52 \%$ & 3 & $11.54 \%$ & 101 & $14.13 \%$ \\
\hline $30-40$ & 49 & $31.41 \%$ & 35 & $29.41 \%$ & 69 & $27.71 \%$ & 48 & $29.09 \%$ & 1 & $3.85 \%$ & 202 & $28.25 \%$ \\
\hline $40-50$ & 33 & $21.15 \%$ & 33 & $27.73 \%$ & 41 & $16.47 \%$ & 52 & $31.52 \%$ & 19 & $73.08 \%$ & 178 & $24.90 \%$ \\
\hline $50-60$ & 14 & $8.97 \%$ & 18 & $15.13 \%$ & 20 & $8.03 \%$ & 14 & $8.48 \%$ & 1 & $3.85 \%$ & 67 & $9.37 \%$ \\
\hline$>60$ & 3 & $1.92 \%$ & 2 & $1.68 \%$ & 6 & $2.41 \%$ & 5 & $3.03 \%$ & 2 & $7.69 \%$ & 18 & $2.52 \%$ \\
\hline Totals & 156 & $100 \%$ & 119 & $100 \%$ & 249 & $100 \%$ & 165 & $100 \%$ & 26 & $100 \%$ & 715 & $100 \%$ \\
\hline
\end{tabular}

In addition, the analysis of the data collected in the five editions of the MOOC show that more than $62 \%$ of those who participated were women $(62.52 \% ; n=447)$ while $37 \%$ were men $(37.20 \% ; n=266)$.

Table 3. Gender of participants

\begin{tabular}{|c|c|c|c|c|c|c|c|c|c|c|c|c|}
\hline \multirow{2}{*}{ Gender } & \multicolumn{2}{|c|}{ 1st_Ed } & \multicolumn{2}{|c|}{ 2nd_Ed } & \multicolumn{2}{|c|}{ 3rd_Ed } & \multicolumn{2}{|c|}{ 4th_Ed } & \multicolumn{2}{|c|}{ 5th_Ed } & \multicolumn{2}{|c|}{ TOTAL } \\
\hline & $f$ & $\%$ & $f$ & $\%$ & $f$ & $\%$ & $f$ & $\%$ & $f$ & $\%$ & $f$ & $\%$ \\
\hline Women & 93 & $59.62 \%$ & 78 & $65.55 \%$ & 155 & $62.25 \%$ & 105 & $63.64 \%$ & 16 & $61.54 \%$ & 447 & $62.52 \%$ \\
\hline Men & 63 & $40.38 \%$ & 41 & $34.45 \%$ & 92 & $36.95 \%$ & 60 & $36.36 \%$ & 10 & $38.46 \%$ & 266 & $37.20 \%$ \\
\hline $\mathrm{DK}^{*}$ & 0 & $0.00 \%$ & 0 & $0.00 \%$ & 2 & $0.80 \%$ & 0 & $0.00 \%$ & 0 & $0.00 \%$ & 2 & $0.28 \%$ \\
\hline Totals & 156 & $100 \%$ & 119 & $100 \%$ & 249 & $100 \%$ & 165 & $100 \%$ & 26 & $100 \%$ & 715 & $100 \%$ \\
\hline
\end{tabular}

Note: DK* (Don't Know responses).

The participants' level of education was one of the variables we considered needed further analysis, since we wanted to find out whether the MOOCs were facilitating access to education for people with lower levels of education or, on the contrary, they were being used mainly by people with higher levels. Data collected reveals that more than $94 \%$ of the students had a university degree $(94.27 \% ; n=674)$. The next largest group consisted of people with medium or higher professional training $(3.50 \% ; n=25)$ followed by those who had completed secondary education $(1.68 \% ; \mathrm{n}=12)$.

Likewise, we wanted to know if the participants' level of education was related in any way with the subject being studied. While the results revealed that more than $43 \%(43.22 \% ; n=309)$ of the participants had an access qualification that was not linked directly to the subject addressed, we found that a significant number of students had taken studies related to the subject (the development of innovative practices with technology). Therefore, almost $28 \%$ had undertaken studies in the field of knowledge relating to educational sciences: Teacher Education (27.55\%; $\mathrm{n}=197)$, Pedagogy $(15.80 \% ; \mathrm{n}=113)$ or Social Education $(3.08 \%$; $\mathrm{n}=22)$ or other related fields, for example, Psychology $(4.06 ; n=29)$. 
Table 4. Participants's studies

\begin{tabular}{lccccccccccccc}
\hline \multirow{2}{*}{$\mathrm{Q}^{*}$} & \multicolumn{2}{c}{1 1st_Ed } & \multicolumn{2}{c}{ 2nd_Ed } & \multicolumn{2}{c}{ 3rd_Ed } & \multicolumn{2}{c}{ 4th_Ed } & \multicolumn{2}{c}{5 th_Ed } & \multicolumn{2}{c}{ TOTAL } \\
\cline { 2 - 14 } & $f$ & $\%$ & $f$ & $\%$ & $f$ & $\%$ & $f$ & $\%$ & $f$ & $\%$ & $f$ & $\%$ \\
\hline TE $^{*}$ & 42 & $26.92 \%$ & 24 & $20.17 \%$ & 95 & $38.15 \%$ & 32 & $19.39 \%$ & 4 & $15.38 \%$ & 197 & $27.55 \%$ \\
Ped $^{*}$ & 21 & $13.46 \%$ & 23 & $19.33 \%$ & 33 & $13.25 \%$ & 30 & $18.18 \%$ & 6 & $23.08 \%$ & 113 & $15.80 \%$ \\
Psy $^{*}$ & 1 & $0.64 \%$ & 3 & $2.52 \%$ & 1 & $0.40 \%$ & 2 & $1.21 \%$ & 0 & $0.00 \%$ & 7 & $0.98 \%$ \\
PsyP $^{*}$ & 6 & $3.85 \%$ & 4 & $3.36 \%$ & 12 & $4.82 \%$ & 5 & $3.03 \%$ & 2 & $7.69 \%$ & 29 & $4.06 \%$ \\
SE $^{*}$ & 5 & $3.21 \%$ & 6 & $5.04 \%$ & 5 & $2.01 \%$ & 6 & $3.64 \%$ & 0 & $0.00 \%$ & 22 & $3.08 \%$ \\
SW $^{*}$ & 0 & $0.00 \%$ & 0 & $0.00 \%$ & 3 & $1.20 \%$ & 2 & $1.21 \%$ & 0 & $0.00 \%$ & 5 & $0.70 \%$ \\
Sclgy & 1 & $0.64 \%$ & 0 & $0.00 \%$ & 4 & $1.61 \%$ & 0 & $0.00 \%$ & 0 & $0.00 \%$ & 5 & $0.70 \%$ \\
Others & 72 & $46.15 \%$ & 50 & $42.02 \%$ & 85 & $34.14 \%$ & 88 & $53.33 \%$ & 14 & $53.85 \%$ & 309 & $43.22 \%$ \\
DK & 8 & $5.13 \%$ & 9 & $7.56 \%$ & 11 & $4.42 \%$ & 0 & $0.00 \%$ & 0 & $0.00 \%$ & 28 & $3.92 \%$ \\
\hline Totals & 156 & $100 \%$ & 119 & $100 \%$ & 249 & $100 \%$ & 165 & $100 \%$ & 26 & $100 \%$ & 715 & $100 \%$ \\
\hline
\end{tabular}

Note. Q* (Qualifications): TE* (Teacher Education); Ped (Pedagogy); Psy* (Psychology); PsyP* (Psychopedagogy); SE* (Social Education); SW* (Social Work); Sclgy* (Sociology).

At the same time, we tried to find out about the students' employment situation since this could be determining their level of participation in the different activities that formed part of this educational process. According to our results we could see that more than $64 \%$ of those who answered the questionnaire $(64.06 \% ; n=458)$ were working in parallel to the MOOC. The second largest group consisted of those who were unemployed $(18.88 \% ; n=135)$, while almost $17 \%$ of the participants were doing some type of training while participating in the MOOC $(16.64 \% ; n=119)$.

Table 5. Participant's employment situation

\begin{tabular}{|c|c|c|c|c|c|c|c|c|c|c|c|c|}
\hline \multirow{2}{*}{$\begin{array}{l}\text { Current } \\
\text { Employmen } \\
\text { Situation }\end{array}$} & \multicolumn{2}{|c|}{ 1st_Ed } & \multicolumn{2}{|c|}{ 2nd_Ed } & \multicolumn{2}{|c|}{ 3rd_Ed } & \multicolumn{2}{|c|}{ 4th_Ed } & \multicolumn{2}{|c|}{ 5th_Ed } & \multicolumn{2}{|c|}{ TOTAL } \\
\hline & $f$ & $\%$ & $f$ & $\%$ & $f$ & $\%$ & $f$ & $\%$ & $f$ & $\%$ & $f$ & $\%$ \\
\hline Active & 110 & $70.51 \%$ & 76 & $63.87 \%$ & 128 & $51.41 \%$ & 121 & $73.33 \%$ & 23 & $88.46 \%$ & 458 & $64.06 \%$ \\
\hline Unemployed & 25 & $16.03 \%$ & 22 & $18.49 \%$ & 57 & $22.89 \%$ & 30 & $18.18 \%$ & 1 & $3.85 \%$ & 135 & $18.88 \%$ \\
\hline Student & 21 & $13.46 \%$ & 21 & $17.65 \%$ & 63 & $25.30 \%$ & 13 & $7.88 \%$ & 1 & $3.85 \%$ & 119 & $16.64 \%$ \\
\hline DK & 0 & $0.00 \%$ & 0 & $0.00 \%$ & 1 & $0.40 \%$ & 1 & $0.61 \%$ & 1 & $3.85 \%$ & 3 & $0.42 \%$ \\
\hline Totals & 156 & $100 \%$ & 119 & $100 \%$ & 249 & $100 \%$ & 165 & $100 \%$ & 26 & $100 \%$ & 715 & $100 \%$ \\
\hline
\end{tabular}

\section{Level of Digital Competence}

Given the subject of the MOOC course, the development of innovative projects with information and communication technologies, we considered it necessary to try to understand what the previous experiences of the students participating in the course were with regard to this issue. In other words, we wanted to find out whether the participants had participated in any experience that had been considered innovative involving the use of digital technology. Consequently, we found that more than half of the students who answered the questionnaire $(51.47 \% ; n=368)$ had not taken part in the development of these types of experiences. 
Table 6. Participants' previous experience of innovative education

\begin{tabular}{|c|c|c|c|c|c|c|c|c|c|c|c|c|}
\hline \multirow{2}{*}{$\begin{array}{l}\text { Previous } \\
\text { Experience }\end{array}$} & \multicolumn{2}{|c|}{ 1st_Ed } & \multicolumn{2}{|c|}{ 2nd_Ed } & \multicolumn{2}{|c|}{ 3rd_Ed } & \multicolumn{2}{|c|}{ 4th_Ed } & \multicolumn{2}{|c|}{ 5th_Ed } & \multicolumn{2}{|c|}{ TOTAL } \\
\hline & $f$ & $\%$ & $f$ & $\%$ & $f$ & $\%$ & $f$ & $\%$ & $f$ & $\%$ & $f$ & $\%$ \\
\hline Yes & 66 & $42.31 \%$ & 56 & $47.06 \%$ & 116 & $46.59 \%$ & 80 & $48.48 \%$ & 15 & $57.69 \%$ & 333 & $46.57 \%$ \\
\hline No & 87 & $55.77 \%$ & 61 & $51.26 \%$ & 127 & $51.00 \%$ & 82 & $49.70 \%$ & 11 & $42.31 \%$ & 368 & $51.47 \%$ \\
\hline DK & 3 & $1.92 \%$ & 2 & $1.68 \%$ & 6 & $2.41 \%$ & 3 & $1.82 \%$ & 0 & $0.00 \%$ & 14 & $1.96 \%$ \\
\hline Totals & 156 & $100 \%$ & 119 & $100 \%$ & 249 & $100 \%$ & 165 & $100 \%$ & 26 & $100 \%$ & 715 & $100 \%$ \\
\hline
\end{tabular}

In parallel, we tried to find out whether those participating in the course had previously designed any kind of educational innovation project with technology. We found that almost $68 \%$ of the sample who answered the questionnaire had never designed this type of experience $(67.97 \% ; n=486)$, compared to $30 \%$ who said they had some kind of previous experience in the design of innovation projects which involved the use of information and communication technologies $(30.63 \% ; \mathrm{n}=219)$.

At the same time and taking into account the subject matter, we believed it necessary to investigate the perception that students had of themselves with regard to their level of competence in managing digital devices (editing texts, searching for information, preparing presentations, etc.). We found that most students considered their level of managing these types of tools was quite good $(40 \% ; n=286)$. Similarly, nearly $30 \%$ of students considered their level of digital competence was quite good $(29.93 \% ; n=214)$ while more than $28 \%$ considered it sufficient $(28.53 \% ; \mathrm{n}=204)$.

We also asked students about their level of activity in their use of social networks (such as Facebook, Pinterest, etc.) as some of the designed MOOC activities were developed through these virtual spaces. We were able to identify that most of the participating students considered themselves active in social networks $(72.73 \%$; $\mathrm{n}=520)$, compared to the group who said that they did not usually use these types of tools $(25.45 \% ; n=182)$.

Table 7. Self-perception on the management of SNS

\begin{tabular}{|c|c|c|c|c|c|c|c|c|c|c|c|c|}
\hline \multirow{2}{*}{$\begin{array}{l}\text { Are you active } \\
\text { in SNS? }\end{array}$} & \multicolumn{2}{|c|}{ 1_Ed } & \multicolumn{2}{|c|}{ 2_Ed } & \multicolumn{2}{|c|}{ 3_Ed } & \multicolumn{2}{|c|}{ 4_Ed } & \multicolumn{2}{|c|}{ 5_Ed } & \multicolumn{2}{|c|}{ TOTAL } \\
\hline & $f$ & $\%$ & $f$ & $\%$ & $f$ & $\%$ & $f$ & $\%$ & $f$ & $\%$ & $f$ & $\%$ \\
\hline Yes & 101 & $64.74 \%$ & 91 & $76.47 \%$ & 196 & $78.71 \%$ & 117 & $70.91 \%$ & 15 & $57.69 \%$ & 520 & $72.73 \%$ \\
\hline No & 53 & $33.97 \%$ & 26 & $21.85 \%$ & 47 & $18.88 \%$ & 45 & $27.27 \%$ & 11 & $42.31 \%$ & 182 & $25.45 \%$ \\
\hline DK & 2 & $1.28 \%$ & 2 & $1.68 \%$ & 6 & $2.41 \%$ & 3 & $1.82 \%$ & 0 & $0.00 \%$ & 13 & $1.82 \%$ \\
\hline Totals & 156 & $100 \%$ & 119 & $100 \%$ & 249 & $100 \%$ & 165 & $100 \%$ & 26 & $100 \%$ & 715 & $100 \%$ \\
\hline
\end{tabular}

Note: SNS (Social Network Sites)

\section{Student Expectations}

Finally, we looked in-depth at the expectations the students had when they enrolled in this MOOC course. In our opinion, a better understanding of the students' possible intentions or expectations could help us to improve the future design of courses and lead to the adoption of curricular decisions that would enable responding to them.

Thus, we could verify that the majority of students tried to learn as much as possible about the subject dealt with in the course $(79.58 \% ; \mathrm{n}=569)$. Although this was the most common objective among students, some of them did not have a particular interest in completing the process, rather they wanted to access the open material on the course, thus recognizing their overall involvement would not be very high $(10,21 \%$; $\mathrm{n}=73 \%)$. Likewise, almost $8 \%(7.55 \% ; \mathrm{n}=54)$ of the sample expressed their main interest to be knowing what a MOOC course consisted of and what the main characteristics of these types of training processes were.

Together with the students' intentions, we wanted to understand what they wanted to achieve on completion of this course, in other words, what use they thought this this experience was going to have with regard 
to their personal or professional development. Thus, almost $84 \%$ enrolled with the expectation that the experience would enable them to extend their previous education $(83.92 \% ; n=600)$. Other results show that more than $8 \%$ of the sample $(8.11 \% ; n=58)$ believed that completing the training process would improve their work situation, while just over $5 \%$ hoped that the course would increase their chance of gaining employment in an institution related to the general subject of the MOOC $(5.03 \% ; n=36)$.

Table 8. Motives for taking the course

\begin{tabular}{|c|c|c|c|c|c|c|c|c|c|c|c|c|}
\hline \multirow{2}{*}{$\begin{array}{l}\text { Why did you } \\
\text { decide to take } \\
\text { this course? }\end{array}$} & \multicolumn{2}{|c|}{ 1_Ed } & \multicolumn{2}{|c|}{ 2_Ed } & \multicolumn{2}{|c|}{ 3_Ed } & \multicolumn{2}{|c|}{ 4_Ed } & \multicolumn{2}{|c|}{ 5_Ed } & \multicolumn{2}{|c|}{ TOTAL } \\
\hline & $f$ & $\%$ & $f$ & $\%$ & $f$ & $\%$ & $f$ & $\%$ & $f$ & $\%$ & $f$ & $\%$ \\
\hline $\begin{array}{l}\text { Extend my } \\
\text { training }\end{array}$ & 134 & $85.90 \%$ & 102 & $85.71 \%$ & 209 & $83.94 \%$ & 131 & $79.39 \%$ & 24 & $92.31 \%$ & 600 & $83.92 \%$ \\
\hline $\begin{array}{l}\text { Improve my } \\
\text { work situation }\end{array}$ & 13 & $8.33 \%$ & 10 & $8.40 \%$ & 20 & $8.03 \%$ & 14 & $8.48 \%$ & 1 & $3.85 \%$ & 58 & $8.11 \%$ \\
\hline $\begin{array}{l}\text { Gaining } \\
\text { employment }\end{array}$ & 3 & $1.92 \%$ & 6 & $5.04 \%$ & 14 & $5.62 \%$ & 12 & $7.27 \%$ & 1 & $3.85 \%$ & 36 & $5.03 \%$ \\
\hline Others & 6 & $3.85 \%$ & 1 & $0.84 \%$ & 6 & $2.41 \%$ & 7 & $4.24 \%$ & 0 & $0.00 \%$ & 20 & $2.80 \%$ \\
\hline DK & 0 & $0.00 \%$ & 0 & $0.00 \%$ & 0 & $0.00 \%$ & 1 & $0.61 \%$ & 0 & $0.00 \%$ & 1 & $0.14 \%$ \\
\hline Totals & 156 & $100 \%$ & 119 & $100 \%$ & 249 & $100 \%$ & 165 & $100 \%$ & 26 & $100 \%$ & 715 & $100 \%$ \\
\hline
\end{tabular}

\section{DISCUSSIONS AND CONCLUSION}

The study we have carried out has allowed us to understand the profile and intentions of students enrolled on these types of training processes. Our analysis has helped to define the characteristics of the participants' profiles, as well as identify some improvements in the future design of these types of courses in an attempt to satisfy the motivations and expectations of the people who take them.

With regard to the socio-demographic characteristics, we identified that the results are in line with the findings of other studies conducted on this subject and demonstrate a similar student profile: a middleaged person, in employment and with higher education qualifications. Although most of them did not come from the field of education, we found that a significant number of students had studies linked to the subject developed, in other words, the design and development of training experiences at different levels of education. As suggested by other studies, the differences with regard to gender could be related to the field of education in which the course is framed, since it is an area mainly made up of women (Bernal Gonzalez, Sanchez Vera, \& Prendes Espinosa, 2016).

Together with the general characteristics of the student profile, the study has provided further insight into certain aspects which help to clarify motivational aspects, as well as the skills required to participate in these types of processes. On the one hand, the information collected on the participants' digital competence corroborates that the selection of this type of course is directly related to technological skills and the prerequisites linked to certain skills required by the participants (Garcia, Tenorio, \& Ramirez, 2015; Ramirez, 2013; Sanchez-Vera, Leon-Urrutia, \& Huge, 2015), as well as a high level of autonomy, typical of graduate students (Brown, 2013). On the other hand, the results demonstrate the participants' expectations, the need to extend their knowledge being the main motivation, as indicated by studies carried on the profile of participants. The lack of attention given to the issues linked to accessibility or the existence of resources that facilitate translation into another language, given that the course has subtitles in English is a determining factor in the selection (Bernal Gonzalez, 2015).

The study carried out highlights the need to continue conducting further research in order to examine indepth the findings referred to earlier. Since our study corroborates the profile of the participant as a lifelong student (De Waard et al., 2011; Hill, 2013b; Liyanagunawardena et al., 2013; Lemos de Carvalho, Cebrian Robles, Cebrian De la Serna, \& Raposo, 2019), we have to question the promise of the democratization of knowledge on which MOOC were based in order to create strategies that help to transform the general tendency that means that most participants on these types of courses have higher education qualifications. 
Despite the hypothetical disruptive potential of these courses and free training under equal conditions (Christensen et al., 2013; Cooperman, 2014; Daniel, 2012; Radford et al., 2014; Torres \& Gago, 2014), the data seems to suggest that, on the contrary, the digital divide has been reinforced, excluding participants who were supposedly going to benefit from the MOOC revolution, to the extent that the profile of participants still does not include a significant number of people without higher education in the countries of the South and North. Therefore, increasing strategies to provide training in different contexts and the possibility of guaranteeing lifelong education to the world population becomes a priority (UNESCO, 2013), as well as facilitating digital inclusion, in an attempt to develop policies of redistribution that allows maximizing the benefits of a training modality that until now, has been mainly used by a reduced group of the population that already has some experience of higher education (Caballo, Caride, Gradaille, \& Pose, 2014; Chauhan, 2014; Jagannathan, 2015; Medina-Salguero \& Aguaded, 2014; Rohs \& Ganz, 2015).

In view of the results obtained, we consider that this type of work allows us to extract some learning that should be taken into account when thinking about the design of these types of courses. Continuing along the lines of previous work, that have tried to link the objectives of the participants taking into account the typology of this training modality (Osuna-Acedo \& Gil Quintana, 2018; Yousef et al., 2015). The results of our research suggest that we must not lose sight of the fact that the design of these experiences should try to satisfy the needs related to lifelong learning (Kop, 2011), the pursuit of personal improvement, the expansion of knowledge and online learning (Downes, 2012; Siemens, 2005) and the review, reuse, redistribution or remixing of content (Wiley, 2007).

The diversity of intentions that motivate the participation of students on the course, shows that the curricular design of these experiences needs to become more flexible, promoting different itineraries, creating spaces for participation which promote a horizontal model of the reconstruction of knowledge, designing strategies focused on promoting interaction between the participants in these types of experiences (Mackness, Bell, \& Funes, 2016; Mackness, Mak, \& Williams, 2010; Zawacki-Richter \& Anderson, 2014; Zawacki-Richter, Bozkurt, Alturkim, \& Aldraiweesh, 2018). In this regard, the results suggest that the design of MOOCs should be based on a social and sustainable curricular and communicative approach, while at the same time fostering interaction and collaborative work. From a pedagogical perspective, the openness that appears to be demanded by students, leads us to link the design of these experiences to the critical curricular tradition, creating environments in which, far from assuming a unidirectional model of communication and educational relationships which are clearly hierarchical, favours interaction and cognitive conflicts between the participants, basing the experiences on more open curricular design, less linked to formal educational processes (De Waard et al., 2011; McLoughlin, 2013). From a communicative point of view, the profiles and interests of participating students suggest that communicative models with a clear focus on communication should be promoted, that is, designed experiences that allow interaction and exchange in order to achieve some shared learning objectives, avoiding the intoxication of contents and pursuing the functionality of the experiences in order to enhance interaction between the participants (Gillani, 2013).

Acknowledgments: This study is funded by the ECO project (E-learning, Communication and Open-Data: Massive Mobile, Ubiquitous and Open Learning) promoted by the European Union within Competitiveness and Innovation Framework Program (CIP). 


\section{BIODATA and CONTACT ADDRESSES of AUTHORS}

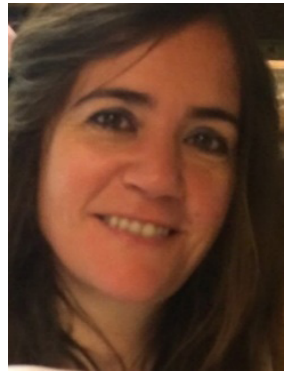

Dr. Elia FERNANDEZ-DIAZ, began her professional career as a Pre-school teacher and currently works as a lecturer in the Department of Education at the University of Cantabria, since 2013. She has worked on research projects aimed at reducing the digital divide such as the European ECO Project: E-Learning, Communication and Open Data and her lines of research include: participatory action research in technologically mediated contexts, critical literacy and disruptive teaching practices in Higher Education and in-service teacher training. She is a Co-ordinating Group member of the University Network of Educational Technology (redrute.es).

Elia FERNANDEZ-DIAZ

University of Cantanbria, Faculty of Education, Department of Education, Address: Edificio Interfacultativo, Avda. Los Castros, 39005 Santander, Spain. Phone: +34942201274

E-mail: fdiazem@unican.es

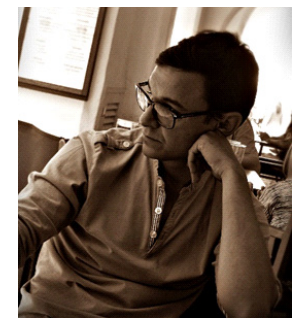

Dr. Carlos RODRIGUEZ-HOYOS, is a senior lecturer at University of Cantabria. He has a Degree in Education and Doctorate awarded by the University of Oviedo. He has been a lecturer in the Department of Education at the University of Cantabria since 2009 and has collaborated on the Modular Program in Digital Technologies and the Knowledge Society at the National University of Distance Education (UNED) since 2006. His lines of research include: the analysis of e-learning from a teaching perspective, ICTs and the dynamics of educational and social inclusion and exclusion.

\section{Carlos RODRIGUEZ-HOYOS}

University of Cantanbria, Faculty of Education, Department of Education, Address: Edificio Interfacultativo, Avda. Los Castros, 39005 Santander, Spain.

Phone: +34942201264

E-mail: rodriguezhc@unican.es

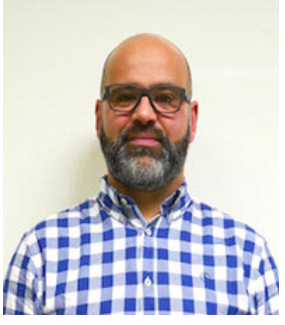

Dr. Jose Luis BELVER DOMINGUEZ, is a Professor at the University of Oviedo (Spain) since 2006. Some of his more relevant research areas include Research Models and Designs on Social-educational Contexts, Assessment of Social-Educational Programs, Analysis and Assessment of Professional Training for Employment, Media Education and Digital Competence. He has published different papers in indexed journals of an international nature related to the aforementioned topics, related as speaker and organizer in more than twenty-five international conferences and is a principal investigator of several research contracts with private companies.

\section{Jose Luis BELVER DOMINGUEZ}

University of Oviedo, Faculty of Teacher Training and Education, Department of Education

Address: C/Aniceto Sela s/n, 33005, Oviedo, Spain.

Phone: +34985102872

E-mail: belverjose@uniovi.es 


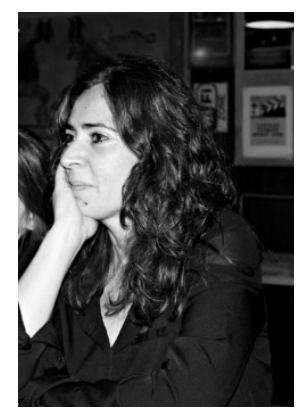

Dr. Adelina CALVO-SALVADOR, is a senior lecturer at University of Cantabria. With a doctorate in Pedagogy (University of Oviedo, Spain), is a lecturer in the Department of Education at the University of Cantabria, Spain, in the area of Didactics and School Organization. Her research interests include socio-educational inclusion/ exclusion mediated by technology, global education, gender and education and school improvement. She has worked on research projects aimed at reducing the digital divide such as the European ECO Project: E-Learning, Communication and Open Data (currently in progress). At present she is Academic Director for Development Cooperation in the Vice-rectorate for Internationalization and Cooperation at the University of Cantabria.

\section{Adelina CALVO-SALVADOR}

University of Cantanbria, Faculty of Education, Department of Education,

Address: Edificio Interfacultativo, Avda. Los Castros, 39005 Santander, Spain.

Phone: +34942201173

E-mail: calvoa@unican.es

\section{REFERENCES}

Adamopoulos, P. (2013). What makes a great MOOC? An interdisciplinary analysis of student retention in online courses. Paper presented at the International Conference on Information Systems, ICIS 2013, Milan. Retrieved from http://pages.stern.nyu.edu/ padamopo/What $\% 20$ makes $\% 20 \mathrm{a} \% 20$ great $\% 20$ MOOC.pdf

Aguado Franco, J. C. (2017). MOOC from a practical perspective. RIED, Revista Iberoamericana de Educacion a Distancia, 20(1), 31-38. https://doi.org/10.5944/ried.20.1

Alarios-Hoyos, C., Estevez-Ayres, I., Perez-Sanagustin, M., Delgado Kloos, C., \& Fernandez-Panadero, C. (2017). Understanding learners' motivation and learning strategies in MOOC. International Review of Research in Open and Distributed Learning, 18(3). http://dx.doi.org/10.19173/irrodl. v18i3.2996

Armstrong, L. (2014). 2013-The Year of Ups and Downs for the MOOCs. Changing Higher Education. Retrieved from http://goo.gl/SqwGWn

Barcena, E., Martin-Monje, E., \& Read, T. (2015). Potentiating the human dimension in Language MOOCs. Proceedings of the European Stakeholder Summit on experiences and best practices in and around MOOCs, EMOOCs 2015, Mons, Belgium, 46-54. Retrieved from http://www. emoocs2015.eu/sites/default/files/Papers.pdf

Barcena, E., \& Read, T. (2015). The role of modularity and mobility in language MOOCS. Verbeia, 1, 2835. Retrieved from http://www.ucjc.edu/book/verbeia-revista-de-estudios-filologicos-no-0/

Belanger, Y., \& Thornton, J. (2013). Biolectricity: A Quantitative Approach. Duke‘s University's First MOOC. Retrieved from: http://dukespace.lib.duke.edu/dspace/bitstream/handle/10161/6216/ Duke_Bioelectricity_MOO C_Fall2012.pdf

Bentley, P., Crump, H., Cuffe, P., Gniadek, B. J., MacNeill, S., \& Mor, Y. (2014). Signals of Success and Self-Directed Learning. Proceedings of EMOOC 2014: European MOOC Stakeholder Summit, Lausanne, Switzerland, pp. 5-10. Retrieved from http://goo.gl/jkHP4q

Bernal Gonzalez, M. (2015). Abandono de los estudiantes en los MOOC [Student dropouts in MOOCs]. (Master Dissertation). University of Murcia. Retrieved from https://digitum.um.es/xmlui/ handle/10201/46706

Bernal Gonzalez, M., Sanchez Vera, M., \& Prendes Espinosa, M. (2016). Intereses y expectativas de los participantes en MOOC: un estudio de caso. [Motivations and expectations of MOOC participants: a case study]. In-Red Conference 2018. Valencia, Spain. http://dx.doi.org/10.4995/ INRED2016.2016.4363

Birnbaum, M. H. (2004). Human research and data collection via the Internet. Annual Review of Psychology, 55, 803-832. http://dx.doi.org/10.1146/annurev.psych.55.090902.141601 
Brazuelo Grund, F., \& Cacheiro Gonzalez, M. L. (2015). Study of adaptability of MOOC platforms to mobile device. RED-Revista de Educacion a Distancia, 48(7). http://dx.doi.org/10.6018/red/47/1

Brown, S. (2013). Back to the future with MOOCs? Proceedings of ICICTE, Crete, Greece. Retrieved from http://www.icicte.org/Proceedings2013/Papers\%202013/06-3-Brown.pdf

Caballo, M. B., Caride, J. A., Gradaille, R., \& Pose, H. M. (2014). Massive open on line courses (MOOCs) like university spread. Profesorado. Revista de Curriculum y Formacion Del Profesorado, 18(1), 43-61. Retrieved from http://www.ugr.es/local/recfpro/rev181ART

Castano Garrido, C. M., Maiz Olazalabaga, I., \& Garay Ruiz, U. (2015). Students' perceptions of a university MOOC. RIED. Revista Iberoamericana de Educacion a Distancia, 15(2), 197-221. https://doi. org/10.5944/ried.18.2

Chang, J. W., \& Wei, H. Y. (2016). Exploring engaging gamification mechanics in massive online open courses. Journal of Educational Technology \& Society, 19(2), 177-203. Retrieved from https:// www.j-ets.net/ETS/journals/19_2/14.pdf

Chauhan, A. (2014). Massive Open Online Courses (MOOCS): Emerging trends in assessment and accreditation. Digital Education Review, 25, 7-17. Retrieved from http://files.eric.ed.gov/ fulltext/ EJ1039698.pdf

Christensen, G., Steinmetz, A., Alcorn, B., Bennett A., Woods, D., \& Emanuel, E. J. (2013). The MOOC phenomenon: Who takes massive open online courses and why? Working Paper. University of Pennsylvania. http://dx.doi.org/10.2139/ssrn.2350964

Colpaert, J. (2016). Foreword. In E. Martin-Monje, I. Elorza, \& B. Garcia Riaza (Eds.), Technologyenhanced language learning for specialized domains (pp. 9-22). London: Routledge.

Cooperman, L. (2014). From elite to mass to universal higher education: from distance to open education. RIED. Revista Iberoamericana de Educacion a Distancia, 17(1), 111-130. https://doi.org/10.5944/ ried.17.1.11576

Daniel, J. (2012). Making Sense of MOOCs: Musings in a maze of myth, paradox and possibility. Journal of Interactive Media in Education, 18(3). Retriewed from http://jime.open.ac.uk/2012/18

Daniel, J., Vazquez Cano, E., \& Gisbert, M. (2015). The future of MOOCs: Adaptive learning or business model? RUSC, Universities and Knowledge Society Journal, 12(1), 64-74. http://dx.doi. org/10.7238/rusc.v12i1.2475

De Waard, I., Abajian, S., Sean Gallagher, M., Hogue, R., Keskin, N., Koutropoulos, A., \& Rodriguez, O. (2011). Using mLearning and MOOCs to understand chaos, emergence, and complexity in education. International Review of Research in Open and Distance Learning, 12(7), 95-115. http://dx.doi.org/10.19173/irrodl.v12i7.1046

Dillahunt, T., Wang, Z., \& Teasley, S. D. (2015). Democratizing Higher Education: Exploring MOOC use among those who cannot afford a higher education. International Review of Research in Open and Distance Learning, 15(5), 177-196. http://dx.doi.org/10.19173/irrodl.v15i5.1841

Downes, S. (2012). Connectivism and Connective Knowledge: Essays on meaning and learning networks. Stephen Downes Web. Retrieved from http://www.downes.ca/post/58207

Fidalgo-Blanco, A., Sein-Echaluce, M. L., \& Garcia-Penalvo, F. (2015). Methodological approach and technological framework to break the current limitations of MOOC model. Journal of Universal Computer Science, 21, 712-734. http://dx.doi.org/10.3217/jucs-021-05-0712

Fini, A. (2009). The technological dimension of a massive open online course: The case of the CCK08 course tools. International Review of Research in Open and Distance Learning, 10(5). Retrieved from http://goo.gl/BhVhbX.

Garcia, B. J., Tenorio, G. C., \& Ramirez, M. S. (2015). Self-motivation challenges for student involvement in the Open Educational Movement with MOOC. RUSC. Universities and Knowledge Society Journal, 12(1), 91-104. http://dx.doi.org/10.7238/rusc.v12i1.2185.

Gillani, N. (2013). Learner Communications in Massively Open Online Courses. (OxCHEPS Occasional Paper 53). Oxford Centre for Higher Education Policy Studies. Retrieved from http://oxcheps. new.ox.ac.uk 
Godwin-Jones, R. (2014). Global reach and local practice: The promise of MOOCS. Language Learning \& Technology, 18(3), 5-15. http://dx.doi.org/10125/44377

Gonzalez, C., Collazos, C., \& Garcia, R. (2016). MOOC design challenges: incorporating collaboration and gamification aspects. RED-Revista de Educacion a Distancia, 48. http://dx.doi.org/10.6018/red/48/7

Gonzalez de la Fuente, A., \& Carabantes Alarcon, D. (2017). MOOCs: measuring satisfaction, loyalty, success and certification of digital education. RIED. Revista Iberoamericana de Educacion a Distancia, 20(1), 105-123. http://dx.doi.org/10.5944/ried.20.1.16820

Hill, P. (2013a). The four student archetypes emerging in MOOCs. e-Literate. Retrieved from http:// mfeldstein.com/the-four-student-archetypes-emerging-in-moocs/7.

Hill, P. (2013b). Emerging student patterns in MOOCs: A (revised) graphical view. e-Literate. Retrieved from http://mfeldstein.com/emerging-student-patterns-in-moocs-a-revised-graphical-view

Jagannathan, S. (2015). Harnessing the power of open learning to share global prosperity and eradicate poverty. In C. J. Bonk, M. M. Lee, T. C. Reeves, \& T. H. Reynolds (Eds.), MOOCs and open education around the world (pp. 219-231). New York: Routledge.

Jordan, K. (2014). Initial trends in enrolment and completion of massive open online courses. The International Review of Research in Open and Distance Learning, 15(1). http://dx.doi.org/10.19173/irrodl. v15i1.1651

Kim, J-I. (2015). A Study on the K-MOOC plataform standarization measures. International Journal of Software Engineering and Its Applications, 9(1), 221-236. http://dx.doi.org/10.14257/ ijseia.2015.9.1.20

Kizilcec, R. F., Piech, C., \& Schneider, E. (2013). Deconstructing disengagement: analyzing learner subpopulations in massive open online courses. Proceedings of the Third International Conference on Learning Analytics and Knowledge, Leuven, Belgium. http://dx.doi. org/10.1145/2460296.2460330

Koller, D., Ng, A., Do, C., \& Chen, Z. (2013). Retention and intention in massive open online courses: In depth. Educause Review. Retrieved from http://goo.gl/DEJzxZ

Kolowich, S. (2012). The MOOC Survivors. Inside Higher Education. Retrieved from http://www. insidehighered.com/news/2012/09/12/edx-explores-demographics-most-persistent-moocstudents

Kop, R. (2011). The challenges to connectivist learning on open online networks: Learning experiences during a massive open online course. The International Review of Research in Open and Distance Learning, 12(3). http://dx.doi.org/10.19173/irrodl.v12i3.882

Kravvaris, D., Ntanis, G., \& Kermanidis, K. L. (2013). Studying massive open online courses: Recommendation in social media. Proceedings of the 17th Panhellenic Conference on Informatics, PCI 2013, Thessaloniki, Greece. Retrieved from https://dl.acm.org/citation.cfm?id=2491845

Lemos de Carvalho, D., Cebrian Robles, D., Cebrian De la Serna, M., \& Raposo, M. (2019). Comparative Study SPOC vs. MOOC for Socio-Technical Contents from Usability and User Satisfaction. TOJDE, The Turkish Online Journal of Distance Education, 20(2), 4-20.

Liyanagunawardena, T. R., Adams, A. A., \& Williams, S. A. (2013). MOOCs: A systematic study of the published literature 2008-2012. International Review of Research in Open and Distance Learning, 14(3), 202-227. http://dx.doi.org/10.19173/irrodl.v14i3.1455

Mackness, J., Bell, F., \& Funes, M. (2016). The rhizome: A problematic metaphor for teaching and learning in a MOOC. Australasian Journal of Educational Technology, 32(1). https://doi.org/10.14742/ ajet. 2486

Mackness, J., Mak, S., \& Williams, R. (2010). The ideals and reality of participating in a MOOC. In L. Dirckinck-Holmfeld, V. Hodgson, C. Jones, M. De Laat, D. McConnell, \& T. Ryberg (Eds), Proceedings of the 7th International Conference on Networked Learning 2010. University of Lancaster, Lancaster, 266-275. Retrieved from http://eprints.port.ac.uk/5605/

Martin-Monje, E., \& Castrillo, M. D. (2016). A redefinition of the teacher and student roles in language MOOCs: The example of "How to succeed in the English-B1 level exam". Paper presented at the LLAS 11th annual e-learning Symposium 2016. Southampton, United Kingdom. 
McLoughlin, C. E. (2013). The pedagogy of personalized learning: exemplars, MOOCS and related learning theories. In J. Herrington, A. Couros, \& V. Irvine (Eds.), Proceedings of EdMedia 2013-World Conference on Educational Media and Technology, Victoria, Canada, 266-270. Retrieved from https://www.learntechlib.org/primary/p/111968/.

McMillan, J.H., \& Schumacher, S. (2001). Research in education: A conceptual introduction. New York: Longman.

Medina-Salguero, R., \& Aguaded, I. (2014). The MOOC in the educational platform MiriadaX. Profesorado. Revista de curriculum y formacion del profesorado, 18(1), 137-153. Retrieved from http://www. ugr.es/local/recfpro/rev181ART8.pdf

Milligan, C., Littlejohn, A., \& Margaryan, A. (2013). Patterns of engagement in connectivist MOOCs. Journal of Online Learning and Teaching, 9(2), 149-159. Retrieved from http://goo.gl/YKIINA.

Osuna-Acedo, S., \& Gil-Quintana, J. (2018). The European project ECO. Breaking down barriers to access knowledge. Educacion XX1, 20(2), 189-213. https://doi.org/10.5944/educXX1.15852.

Perifanou, M. (2015). Personalized MOOCs for language learning: A challenging proposal. ELearning Papers, 45. Retrieved from goo.gl/ZKcSHg

Poy, R., \& Gonzales-Aguilar, A. (2014). MOOC success factors: some critical considerations. RISTI. Revista Iberica de Sistemas de Tecnologia de la Informacion, 1(3), 95-118. Retrieved from http://www. academypublisher.com/risti/no13/risti13.pdf

Radford, A. W., Robles, J., Cataylo, S., Horn, L., Thornton, J., \&Whitfield, K. (2014). The employer potential of MOOCs: a survey of human resource professionals' thinking on MOOCs. RTI International. Retrieved from http://www.rti.org/pubs/duke_handbook-final-03252014.pdf

Ramirez, M. (2013). Competencias Docentes y Practicas Educativas Abiertas en la Educacion a Distancia [Teachers competencies and open educational practices in Distance Education]. Monterrey: LULU editorial digital. Retrieved from https://goo.gl/y8Yp1m

Read, T. (2014). The architectonics of MOOCs. In E. Martin-Monje, \& E. Barcena (Eds.), Language MOOCs: providing learning, transcending boundaries (pp. 91-105). Berlin: De Gruyter Open. Retrieved from http://www.degruyter.com/viewbooktoc/product/455678

Rodriguez-Ascaso, A., \& Boticario, J. G. (2015). Accesibility and MOOC: towards a holistic perspective. RIED. Revista Iberoamericana de Educacion a Distancia, 18(2), 61-85. https://doi.org/10.5944/ ried.18.2.1367

Rohs, M., \& Ganz, M. (2015). MOOCs and the claim of education for all: A disillusion by empirical data. International Review of Research in Open and Distributed Learning, 16(6). http://dx.doi. org/10.19173/irrodl.v16i6.2033

Rubio, F., Fuchs, C., \& Dixon, E. (2016). MOOCs better by design. In E. Martin-Monje, I. Elorza, \& B. Garcia Riaza (Eds.), Technology-enhanced language learning for specialized domains (pp. 177188). London, United Kingdom: Routledge.

Sanchez-Gordon, S., \& Lujan-Mora, S. (2013). Web accessibility of MOOCs for elderly students. Paper presented at the 2013 12th International Conference on Information Technology Based Higher Education and Training, Antalya, Turkey. http://dx.doi.org/10.1109/ITHET.2013.6671024

Sanchez-Vera, M. M., Leon-Urrutia, M., \& Huge, D. (2015). Challenges in the creation, development and implementation of MOOCs: Web Science Course at the University of Southampton. Comunicar, 44(22). https://doi.org/10.3916/C44-2015-04

Sedano Cuevas, B. (2017). Attending to the specific needs and demands of students in a globalised world: the case of a 'Spanish for travelling MOOC'. RIED. Revista Iberoamericana de Educacion a Distancia, 20(1), 161-182. http://dx.doi.org/10.5944/ried.20.1.16692

Sharples, M., Delgado C., Dimitriadis, Y., Garlatti, S., \& Specht, M. (2015). Mobile and accessible learning for MOOCs. Journal of Interactive Media in Education, 2015(1), p. Art. 4. http://doi. org/10.5334/jime.ai

Siemens, G. (2005). Connectivism: A learning theory for the digital age. Journal of Instructional Technology and Distance Learning, 1(2). Retrieved from http://www.ingedewaard.net/papers/ connectivism/2005_siemens_ALearningTheoryForTheDigitalAge.pdf 
Teixeira, A., Garcia-Cabot, A., Garcia-Lopez, E., Mota, J., \& De-Marcos, L. (2016). A new competencebased approach for personalizing MOOCs in a mobile collaborative and networked environment. RIED. Revista Iberoamericana de Educacion a Distancia, 19(1), 143-160. http://dx.doi. org/10.5944/ried.19.1.14578

Teixeira, A., \& Mota, J. (2014). A proposal for the methodological design of collaborative language MOOCs. In E. Martin-Monje, \& E. Barcena (Eds.), Language MOOCs: providing learning, transcending boundaries (pp. 33-47). Berlin: De Gruyter Open. Retrieved from http://www.degruyter.com/ viewbooktoc/product/ 455678

Telefonica Foundation (2015). MOOCs in the Education of the Future: Digitizing Training. Retrieved from https://www.fundaciontelefonica.com/arte_cultura/publicaciones-listado/pagina-itempublicaciones/itempubli/324/

Torres, D., \& Gago, D. (2014). The role of MOOCS in the creation of learning and participation communities. RIED. Revista Iberoamericana de Educacion a Distancia, 17(1), 13-34. Retrieved from http://revistas.uned.es/index.php/ried/article/view/11570

UNESCO (2013). Policy guidelines for mobile learning. Paris: United Nations Educational, Scientific and Cultural Organization.

University of Edinburgh (2013). MOOCs @ Edinburgh 2013: report \#1.The University of Edinburgh. Retrieved from https://www.era.lib.ed.ac.uk/handle/1842/6683>

Vazquez-Cano, E., \& Lopez-Meneses, E. (2015). The educational philosophy of MOOCs and University education. RIED. Revista Iberoamericana de Educacion a Distancia, 15(2), 25-37. https://doi. org/10.5944/ried.18.2

Wang, Y., \& Baker, R. (2018). Grit and intention: Why do learners complete MOOCs? International Review of Research in Open and Distributed Learning, 19(3). http://dx.doi.org/10.19173/irrodl. v19i3.3393

White, S., Davis, H., Dickens, K. P., Leon, M., \& Sanchez Vera, M. (2015). MOOCs: What motivates producers and participants? In S. Zvacek, M.T. Restivo, J. Uhomoibhi, \& M. Helfert (Eds.), Proceedings of the 6th international conference on computer supported education, Barcelona, Spain (pp. 99-114). Heidelberg, DE: Springer.

Wiley, D. (2007). On the Sustainability of Open Educational Resource. Initiatives in Higher Education. OECD's Centre for Educational Research and Innovation (CERI). OECD Publishing. Retrieved from http://www.oecd.org/dataoecd/33/9/38645447.pdf

Yang, D., Shina, T., Adamson, D., \& Rosa, C. P. (2013). Turn on, tune in, drop out: Anticipating students' dropouts in massive open online courses. Proceedings of the 2013 NIPS Data-Driven Education Workshop, Lake Tahoe, Nevada, USA. Retrieved from http://goo.gl/t2qtIm

Yousef, A. M. F., Chatti, M. A., Schroeder, U., Wosnitza, M., \& Jakobs, H. (2014). MOOCs a review of the state-of-the-art. Paper presented at the 6th International Conference on Computer Supported Education, CSEDU 2014, Barcelona, Spain.

Yousef, A. M. F., Chatti, M. A., Wosnitza, M., \& Schroeder, U. (2015). A cluster analysis of MOOC stakeholder perspectives. RUSC, Universities and Knowledge Society Journal, 12(1), 74-91. http://dx.doi.org/10.7238/rusc.v12i1.2253

Zancanaro, A., \& Domingues, M. J. (2017). Analysis of the scientific literature on Massive Open Online Courses (MOOCs). Revista Iberoamericana de Educacion a Distancia, RIED, 20(1), 59-80. https://doi.org/10.5944/ried.20.1.15910

Zawacki-Richter, O., \&Anderson, T. (2014). Onlinedistanceeducation-towardsa researchagenda.Edmonton, Canada: Athabasca University Press. https://doi.org/10.15215/aupress/9781927356623.01

Zawacki-Richter, O., Bozkurt, A., Alturkim, U., \& Aldraiweesh, A. (2018). What research says about MOOCS- an explorative content analysis. International Review of Research in Open and Distributed Learning, 19(1). http://dx.doi.org/10.19173/irrodl.v19i1.3356

Zhou, J. (2017). Exploring the factors affecting learners' continuance intention of MOOCs for online collaborative learning: An extended ECM perspective. Australasian Journal of Educational Technology, 33(5), 123-135. https://doi.org/10.14742/ajet.2914 